\title{
Ensaio de semiótica perspectivista: as revoltas de Junho de 2013 e a política da significação
}

\author{
André Fogliano' \\ https://orcid.org/0000-0001-9475-9728 \\ I - Concordia University \\ Montreal, Canadá
}

Resumo: Acontecimentos com a intensidade das revoltas de Junho de 2013 no Brasil colocam um problema incontornável para os teóricos da comunicação e da semiótica: a política da significação. A multiplicidade de percepções e de sentidos nos traz de volta o problema da relação entre fato e representação, entre objeto de enunciado e sujeito de enunciação. A revolta não é um dado inerte passível de múltiplas representações, mas é uma multiplicidade absoluta de agenciamentos em constante disputa. Os sujeitos e objetos da enunciação são muito mais um efeito da política de significação instaurada do que a condição de possibilidade dos discursos sobre a revolta. Como formular um diagnóstico com focos de enunciação tão instáveis, sem as dualidades prescritivas de praxe? O presente ensaio parte dessa problemática para pensar uma semiótica perspectivista no enredamento entre a antropologia de Viveiros de Castro e o processo aberto pelas revoltas de Junho.

Palavras-chaves: revoltas de Junho de 2013; semiótica; perspectivismo.

Abstract: Perspectivist Semiotics essay: The protests of June 2013 and the politics of signification Intense events such as the protests of June 2013 in Brazil pose a problem for media theorists and semioticians: the politics of signification. The multitude of perceptions and meanings detours a fundamental semiotic paradigm: the relashionship between fact and representation, object of statement and subject of enunciation. The riot is not an amorphous fact upon which a variety of meanings and representations would apply, but it is an expression of an absolute multiplicity of agencies in constant dispute. Subjects and objects of enunciation are rather the effect of a politics of meaning than the condition of possibility of any statements accounting the riots. How do we craft a diagnosis with such unstable points of view, escaping from prescriptive dichotomies? This essay starts from this problem in order to elaborate a perspectivist semiotics that interlaces the anthropology of de Castro with the radical process initiated by the protests of June.

Keywords: revolts of June 2013; semiotics; perspectivism. 


\section{Introdução}

Antes de mais nada, é possível dizer que as revoltas de Junho de 2013, a malha de levantes que proliferou pelas ruas e redes de todo o Brasil, que, entre idas e vindas, durou de junho daquele ano até meados de 2014, são um problema de percepção e de sentido. Se é possível assinalar algo do levante é sua natureza propriamente inassinalável. No entanto, o inassinalável não é sinônimo de sem sentido; ao contrário, é a acumulação de uma variada gama de sentidos e perspectivas moventes e permutáveis. Distintos agenciamentos sociais perceberam, viveram e ainda vivem as revoltas de um modo singular. De certo modo, as revoltas tiveram como efeito uma desnaturalização da forma de perceber as relações sociais e uma abertura para uma reconfiguração multiplicada de seus sentidos. A rebelião de Junho fez irromper uma fenda na linearidade histórica desde a qual percepções, sentidos e perspectivas novas passaram a se insinuar violentamente (da heterotopia anarquista aos neoarcaísmos).

Para os teóricos da comunicação e da semiótica, acontecimentos com a intensidade das revoltas de Junho colocam uma questão incontornável: a política da significação um dos problemas fundamentais, por exemplo, de Elementos de semiologia, de Barthes (2006). A multiplicidade de percepções e de sentidos nos traz de volta um dos problemas semióticos mais graves, qual seja, a relação entre fato e representação, entre coisa e palavra, entre mundo e linguagem. Não quero dizer com isso, simplesmente, que Junho constituiu um impasse de significação, que o acontecimento permaneceu irredutível a qualquer representação, como que inacessível e, por essa razão, passível de múltiplas representações. Esse é ainda um falso problema. O problema da significação decorre da singularidade de um acontecimento que, antes de ser irredutível a qualquer representação, é uma multiplicidade absoluta de coisas em constante movência e mistura. A revolta não é um fato objetivo passível de múltiplas significações ou representações. A revolta é expressão da inconstância, da variação e da disputa pela objetificação ou da significação do fato. O que é múltiplo e movente não é mais a representação, mas o próprio fato, o próprio objeto, a própria natureza da realidade.

Neste ensaio, procuro apresentar alguns pontos de uma pesquisa de pós-doutorado ${ }^{1}$ em curso que tem por objetivo estruturar a semiótica perspectivista como ferramenta de análise de acontecimentos sociocomunicacionais (ALZAMORA; RODRIGUES, 2014). Em específico, analiso o caso de prisão de Bruno Teles ocorrido durante as revoltas de 2013, e que ficou conhecido por seu caráter midiático. A antropologia pósestruturalista de Eduardo Viveiros de Castro serve de substrato para essa proposta. Essa antropologia oferece um modo de leitura que permite escapar das aporias da polarização que vige, em grande medida, nas análises do discurso do atual estado de coisas².

1 O estudo é desenvolvido no Senselab, laboratório sediado na Concordia University (Montreal).

2 Remeto aos artigos de Prado e Prates (2018a; 2018b) e Demuru (2018; 2017). 
Sem buscar ferramentas conceituais que escapem do cânone da epistemologia Moderna, será difícil formular diagnósticos apropriados do que se passa no mundo hodierno.

\section{O que pode a semiótica?}

De pronto, cabe marcar que a semiótica com a qual trabalhamos não se restringe ao estudo da língua ou da linguagem verbal. A semiótica constitui um procedimento de leitura de processos de ação sígnica. Sendo assim, filio-me mais à semiótica dos afetos de Espinoza, Peirce e Deleuze, como a define da Costa (2018), do que as teorias semióticas orientadas exclusivamente para as análises do discurso. Nesse sentido, a semiótica desloca e expande o problema da semiose para aquém e além do esquadro do humano, não restringindo seu campo de análise apenas aos signos verbais. A produção, a percepção e a interpretação de signos não são um privilégio exclusivo do humano.

O humano é, aqui, a expressão de um modo de vida geneticamente vinculado com a civilização moderna, fruto do progresso de uma longa travessia antropotécnica. Nas fronteiras desse modelo civilizatório, como diz Viveiros de Castro (2015), todo mundo é humano, exceto quem não é: indígenas, quilombolas, negros e negras, as $n$ sexualidades, bem como os animais, as plantas, as águas, a terra, o ar, o cosmos. Em suma: tudo aquilo que difere, tudo aquilo que não é espelho. Tudo o que não devolve a imagem da pele e da máscara branca, racional, eurocêntrica, hetero, cristã, burguesa, empreendedora etc. Esses corpos outros estão alijados da semiose humana, demasiada humana. Apenas essa formaHomem maneja signos, apenas ela confecciona significações. A pluralidade do cosmos só ganha sentido quando passa pelo crivo do humano ocidental: o Homem euro-moderno.

Para que a antropotécnica semiológica funcione, é preciso um pressuposto metafísico que bifurca o mundo em metades descontínuas. De um lado, a Cultura (o mundo suprassensível), de outro, a Natureza (o mundo sensível), e seus duos avatares. Essa bifurcação nega o direito de autodeterminação ontológica a todos os corpos da natureza. Só o humano (euro-moderno) é ser existente, configurador de mundos. O Homem-moderno é um Império dentro de um império, o estado de exceção da natureza. Os demais entes são, no limite, corpos sem direito à vida, sem estatuto ontológico, passíveis de qualquer tipo de intervenção, posto que possuem, quando muito, uma cultura em estado primitivo.

No entanto, o que experimentamos com as revoltas de Junho, e com o sistema-rede de levantes globais abertos pela Primavera Árabe, com as crises políticas, econômicas e ecológicas contemporâneas, é a impossibilidade dessa visão bifurcante do mundo permanecer firmemente ancorada. A longa travessia do humanismo da Idade Moderna nos termos em que nos acostumamos está perto do fim, a Europa deixa de ser o umbigo do mundo (MBEMBE, 2017). Muitos estudiosos das revoltas de Junho enunciam tal diagnóstico, percebem que Junho anuncia o crepúsculo dessa episteme. Schavelzon comenta que da ressaca de todas as crises "ficamos com algo: o mundo não é mais só um". 
Jourdan (2018), em seu livro de memórias, em que revisita seus dias no calabouço de Bangu por sua atividade política durante o levante, chega a semelhante conclusão quando afirma categoricamente que Junho dá fim a essa ontologia dualista, ou seja, pensar Junho requer uma experiência com outras metafísicas. Em O enigma do disforme (2018), Cocco e Cava tentam extrair dessa transformação ontológica as consequências políticas. Seja como for, doravante, jamais permaneceremos sendo apenas modernos - esse é o problema. A semiologia antropotécnica sustentada na bifurcação do mundo, segundo a qual a natureza restava na coxia da cena, na obscena, aparecendo como um ente amorfo, dado e inacessível, se vê obrigada a compartilhar o mundo com outros mundos.

Esses mundos múltiplos não significam, contudo, múltiplas culturas que falam de um só mundo. Não é de relativismo que se trata. O mundo não é dado, ele é uma variante, um variado, é variação. Cada partícula do cosmos expressa uma camada de vida, um grau de potência. Todavia, a multiplicidade de mundos em coexistência não entrega uma paz total, mas movimenta um estado permanente de risco, de disputa, de guerra. Não há linguagem universal que dê conta de uma esfera pública onde o consenso será cerzido entre mundos em igualdade de condições e de lugares de fala. O consenso presume que esses mundos conversem dentro da mesma linguagem, da mesma gramática, algo que não parece mais ser viável, nem desejável. Isso abre uma crise sem precedentes para a teoria geral dos signos e da comunicação, uma vez que, em geral, tais teorias se fundamentam no falso problema da bifurcação da natureza. Tudo se passa como se o humano estivesse sozinho no mundo, solipsista. Só há comunicação intraespécie, pois a morada do ser é a linguagem. Só os humanos comunicam, e comunicam tão somente entre si.

Cada vez mais, contudo, a experiência do mundo atual estremece a antropotécnica semiológica. Dá para afirmar, sem hesitação, que essa antropotécnica só se sustenta porque pode, isto é, porque tem força política, econômica, militar, midiática para fazê-lo. Em todo o caso, como defendi em Fogliano (2017), acredito que as revoltas de Junho devem ser vistas, ainda, como uma semiose aberrante que abre os caminhos para driblarmos os pressupostos da semiológica antropocêntrica.

\section{O perspectivismo multinaturalista}

A antropologia de Eduardo Viveiros de Castro é máquina de guerra indispensável para destituir a pregnância da antropotécnica da Idade Moderna. O perspectivismo multinaturalista de Viveiros de Castro dá a pensar um procedimento semiótico poderoso para inteligir essa rizomática de mundos em mistura. O autor evidencia isso em $O$ medo dos outros (2011): "O importante aqui é lembrar que no perspectivismo há mais do que a vista alcança: há toda uma teoria do signo e da comunicação" (grifo nosso).

De Castro (2015) retoma uma anedota de Lévi-Strauss para extrair dela as consequências conceituais e políticas do perspectivismo. No período inicial do genocídio 
colonizante, enquanto na metrópole os jesuítas especulavam em comissões de inquérito se o corpo do índio possuía ou não alma, nas capitanias, os índios estudavam os brancos aprisionados para verificar se o corpo do europeu apodrecia ou não. Lévi-Strauss quer reforçar com essa parábola a intrínseca avareza humana de conceber humanidade à alteridade. De um lado, o etnocentrismo europeu pensava (pensa) estar diante de uma versão ainda animal (sem cultura, incivilizada) do humano, imagem do que os europeus tinham sido no passado; de outro, o etnocentrismo indígena desconfiava estar diante de divindades, não deuses propriamente, mas da proto-humanidade dos mitos. Os civilizados duvidavam (duvidam) que os selvagens possuíam espírito humano, pois é esse atributo que os assegura a humanidade. Os selvagens questionavam se os civilizados possuíam corpos, pois é esse atributo que os assegura a humanidade.

Viveiros de Castro não reconhece nessa anedota, contudo, uma identidade avara entre selvagens e civilizados. A avareza se manifesta diferentemente nos dois casos. O modo de colocar o problema é radicalmente diferente, uma diferença de natureza, e não de grau. A equivocidade do exemplo expressa a experiência de humanidade vivida por cada cultura. Por um lado, o selvagem concebe o Outro com o Mesmo de si mesmo, eles partilham a mesma cultura, mas duvidam possuir o mesmo corpo. O civilizado concebe, por seu turno, o Outro sem o Mesmo de si mesmo, eles partilham o mesmo corpo, mas duvidam possuir a mesma alma, a mesma cultura. "O outro do Outro não era exatamente o mesmo que o Outro do mesmo (DE CASTRO, 2015, p. 36). Ou ainda: "Os outros foram o que somos, e não, como entre nós, são o que fomos" (DE CASTRO, 1996). O Grande Divisor não opera igualmente nos dois casos, natureza e cultura são dispositivos diferentemente mobilizados e ordenados. Os selvagens não percebem a Divisão como descontinuidade, como fazem os civilizados. Se para o pensamento dominante do Ocidente existiria um mais-valor cognitivo na ruptura da cultura com a natureza, para os ameríndios não há descontinuidade entre natureza e cultura.

Dito de outra forma, para os nativos ameríndios existe um modo universal de acessar, conhecer ou representar o real: o humano. Para eles, segundo Viveiros de Castro, existe uma só epistemologia (a cultura humana) e uma multiplicidade inconstante de mundos, uma natureza de corpos absolutamente múltipla. Tem-se aí o avesso do mononaturalismo que afirma a existência de uma só natureza com sua multiplicidade de interpretações. Um multinaturalismo ontológico, de um lado, um multiculturalismo epistemológico, de outro. A ontologia ameríndia atribui função semiótica ao corpo e à alma simetricamente distinta da adotada pelo Ocidente. Para aqueles, o fundo comum é o espírito ou a cultura, o que implica o gesto de fazer corpos, de diferenciar espécies; para nós, o fundo comum é o corpo, trata-se de fazer almas, de diferenciar culturas. Para os selvagens existe um único modo de conhecer o mundo, mas múltiplos modos de percebê-lo. A centralidade está no corpo, na sua capacidade de afetar e ser afetado. O que é distinto da fórmula de que há um único modo de perceber o mundo e múltiplos modos de conhecê-lo e de representá-lo. 
Reside aí uma questão política crucial. O multiculturalismo inclui apenas povos ou mundos da mesma espécie dentro de sua economia política solipsista. E sabemos bem que, no fundo, essa inclusão opera por exclusão. A cultura, por assim dizer, mais verdadeira, a que mais se aproximou da ideia universal de humanidade, é a Moderna. O resto é, no melhor dos casos, exotismo, e, no pior, primitivismo, incivilidade. Para os modernos, existem humanos com mais direito à humanidade que outros, sem considerar o fato de que as outras entidades cósmicas não possuem direito algum. Por sua vez, a política ameríndia insere todos os seres da natureza, humanos, nãohumanos e extra-humanos em sua economia política cósmica. A política ameríndia se estende a todo o cosmos. É uma cosmopolítica, nesse sentido. O importante a ser acentuado é que esse universalismo da pessoa, para os nativos, não é apenas um problema restrito às imagens mitológicas, onde haveria uma zona de indiscernibilidade entre os seres, na qual humanos e animais ainda não haviam entrado em processo de especiação. Esse universalismo da condição humana na vida pós-mítica funciona em um estado de perigosa não aparência, de latência ou de potencialidade.

\begin{abstract}
Todo ser com que um humano se confronta, ao longo do processo de produção da própria vida, pode subitamente fazer passar à frente de sua aparência não humana usual o seu "outro lado" (idioma comum nas cosmologias indígenas), atualizando sua condição humanoide de fundo e colocando automaticamente em risco de vida, e de categoria, o interlocutor humano. (DE CASTRO, 2011)
\end{abstract}

Eis um segundo ponto fundamental que cabe abordar para destrinchar a semiótica perspectivista. Trata-se do canibalismo. Entre os povos da floresta, o problema da predação generalizada é o que dinamiza e organiza toda a conexão social do desejo. A predação e a caça dão o sentido do que eles concebem como uma guerra transespecífica. Em O medo dos Outros (2011), o autor se pergunta do quê os índios têm medo? Precisamente, eles têm medo de virar presa. Isso significa, entre outras coisas, que a nomeação dos acontecimentos dessas sociedades é determinada pelo binômio predador/presa. Como disse em Fogliano (2017, p. 208): "todo o jogo político-semiótico segue a série sujeito de enunciação/predador <-> objeto do enunciado/presa". Todo povo tem sua alteridade radical à espreita, um predador, um inimigo rondando a mata. Nessas sociedades, todos são potencialmente e concomitantemente predadores e presas. Tudo será decidido no acontecimento, tudo derivará do campo relacional de manducação que se estabelece no encontro na mata. As relações políticas transespecíficas dos povos da floresta são estabelecidas em conformação com a cadeia trófica, são disputadas pela boca.

No mesmo texto, Viveiros de Castro sublinha que "o maior perigo na vida é o fato da comida humana consistir inteiramente de almas". O perigo decorre da condição de que todo ente é virtualmente um foco de agência, um grau de potência. E isso menos no sentido da presa ser humana, mas da incerteza de que ela pode ter sido, pode ser ou 
vir a ser gente. Mais ainda, a realização de qualquer uma dessas ocasiões indica que, se a presa nãohumana devém humana, o risco do humano devir nãohumano é real, o que na sociedade ameríndia é um problema político fundamental, visto que é essa política da indeterminabilidade que determinará quem é o sujeito e quem é o objeto da relação, isto é, o devorador e o devorado. Donde essa inquietante sensação de incerteza do predador ao se confrontar com a presa.

A cultura humana é, em certo sentido, o que há de mais bem distribuído e partilhado. Tudo foi, é ou pode vir a ser animado pela agência humana. Na floresta, quando predador e presa se encontram o que está em jogo é a afirmação da perspectiva humana de cada um, uma vez que o humano é sempre o agente, o sujeito, o predador da relação. Cada modo existente, cada ponto de vista, apreende a multiplicidade dos outros modos existentes e dos outros pontos de vista segundo suas próprias características de existente. $\mathrm{Na}$ natureza selvagem, cada povo atribui sentido aos outros povos humanos, nãohumanos e extrahumanos a partir de uma perspectiva universal: a humana (mas, como de Castro afirma, onde tudo é humano, o humano é todo uma coisa outra). Todos percebem a realidade segundo um mesmo modo. Contudo, não há uma homogeneidade das percepções. O multinaturalismo é radical. A consideração de que a natureza é fixa é confrontada com uma variação contínua e incessante. É entre os animais predadores, sobretudo - como dissemos a pessoalidade não se aplica a todos necessariamente, ela é uma potência -, que essa dinâmica mais se acentua. Por exemplo, os urubus são um povo específico, estruturam-se em sociedade, com instituições como a dos humanos, com chefes, xamãs, festas e ritos, os atributos corporais, bicos, plumagem, asas, são adornos ou instrumentos culturais, e os vermes da carne podre são peixe assado (DE CASTRO, 2015, p. 44). As onças veem o sangue como cauim, as antas experimentam o barro lamacento como uma grande casa cerimonial. Assim, quando o humano (o indígena) se depara com seu predador (a onça) há uma disputa de perspectiva, a onça não vê a presa humana como gente, mas como presa, seu sangue é cauim. Essa gentificação, o modo de se conceber como gente e os demais existentes como animais ou espíritos, é relativa à posição ou à série ocupada dentro da cadeia trófica. A lógica é a da pressuposição recíproca, "algo também só é peixe porque existe alguém de quem este algo é o peixe" (DE CASTRO, 2002, p. 384), assim como alguém só é pai ou mãe porque existe um filho e vice-versa, e apenas envelopados nessa relação que ambos podem ser pai, mãe e filho um do outro. A relação é exterior, precede e funda os termos, e não o inverso. Portanto, não se trata de uma multiplicidade de pontos de vista, ou um relativismo dos pontos de vistas, o que obrigatoriamente nos reconduziria ao multiculturalismo vigente. Antes, trata-se de tomar o ponto de vista como multiplicidade. Quando o índio e o urubu olham para a carne decomposta (no caso do urubu a carne putrefata é peixe) eles não estão vendo a mesma coisa, atribuindo, cada um ao modo de sua cultura, uma noção comum sinonímica para o objeto apreendido. Não existe a coisa em si mesma que cada cultura dará uma expressão distinta. Melhor: a coisa em si existe, mas ela é paradoxalmente variação. 


\title{
As revoltas de Junho e a semiótica perspectivista
}

Tentei extrair as consequências semióticas dessa antropologia em (FOGLIANO, 2017). Do ponto de vista semiótico, isso significa dizer que todos os seres existentes são potencialmente focos de enunciação, sujeitos de enunciação. Nas sociedades ameríndias, essas posições semióticas são dêiticos cosmológicos (DE CASTRO, 1996). Quando alguém diz eu, mais ainda nós, esse corpo está pondo em perspectiva um agenciamento enunciativo que envolve o cosmo inteiro. O cosmo inteiro se individua naquele instante. Como afirmei em Fogliano (2017, p. 210):

\begin{abstract}
Não se trata nem mesmo de um sujeito de enunciação propriamente, mas de um agenciamento coletivo de enunciação fixado naquele específico e instável encontro na mata. A relação que marca o regime de signos da modernidade, sujeito de enunciação $\measuredangle \rightarrow$ objeto do enunciado, entra em parafuso. A semiótica perspectivista não possui um centro de enunciação unificador (um cogito), o que significa dizer que é um sistema aberto com uma multiplicidade cósmica de microcentros de expressão. Excesso de comunicação, o avesso do solipsismo. Nada está garantido de antemão, não há ponto de homogeneização, de estabilização dados. Melhor ainda, essa economia selvagem dos signos trabalha para obstruir a estratificação de dispositivos de poder-saber com função integradora, homogeneizante, totalizadora (não há nem Estado, nem Capital, nem Mídia, nem Polícia).
\end{abstract}

Tomemos para exercício desse procedimento de leitura um dos acontecimentos mais instigantes, poderíamos dizer, selvagem, ingovernável, das revoltas: os black blocs. Os black blocs tornaram-se personagens primordiais do levante, em vários níveis. Uma das maneiras de enfraquecer a potência subjetiva desse novo agenciamento foi justamente objetificálo, transformá-lo em coisa, ser sem humanidade. O atributo incorporal para a realização dessa reificação foi o de vândalo. Esse atributo serviu e serve, recorrentemente, nesses eventos insurgentes, para decantar os bons manifestantes, os manifestantes civilizados, razoáveis, daqueles incivilizados, violentos. Esse termo tem, por fim, transformar os sujeitos de enunciação que se insinuavam, em coisas, em objetos sem vida, desumanos. Os black blocs não poderiam ser sujeitos de enunciação, posto que não possuíam humanidade suficiente para tanto. E, como é sabido, aquele que carece de humanidade, aquele que aparece como objeto da relação, torna-se potencialmente presa, está em vias de ser devorado. E não estamos mais nos referindo às sociedades ameríndias. A tentativa de transformar esses possíveis sujeitos de enunciação em objetos é realizável por um exercício político-semiótico, pelo uso de um atributo incorporal - vândalos, violentos, mascarados, são exemplos certeiros - expresso por um sujeito de enunciado naturalizado como o Estado, a Polícia Militar ou a Mídia. Se houver sucesso, a semiose aberrante é transmutada em coisa, é desumanizada, torna-se o objeto da enunciação. Esses corpos ficam, assim, 
vulneráveis a toda sorte de investimento, uma vez que são ditos e vistos como objetos, como nãohumanos. Aquele que perde sua condição de agente, de foco de enunciação, sem o devido cuidado, corre o risco de virar presa, objeto, ser comido, devorado.

De Castro (2011) traça uma analogia entre a experiência virtualmente perigosa do encontro com o predador nas selvas ameríndias, com a experiência igualmente perigosa e violenta do encontro com o predador nas selvas de pedra capitalistas. No primeiro caso, o jaguar é a alteridade absoluta sempre à espreita por entre as frestas moventes da floresta. No segundo, a Polícia Militar, a encarnação do Estado, é a alteridade absoluta virtualmente à espreita por entre as frestas, principalmente, dos guetos e das vielas do asfalto periférico. O jaguar, figura do predador das sociedades ameríndias, exerce a mesma função do Estado, figura do predador nas sociedades capitalistas. A sensação que eles provocam é a mesma em ambas as culturas: a desumanização, a objetificação. O Estado-Jaguar tem o poder de roubar a humanidade dos corpos com os quais cruzam nos encontros e desencontros da cidade-selva. Quando um existente assumir essa função (o policial, a jornalista, o capitalista, a onça, o jaguar, o urubu etc.) e interpelar o outro fazendo do outro a segunda pessoa da relação, ela corre o risco de se desumanizar, de transmutar-se em objeto, virar coisa. Poderá ser, enfim, devorado.

Essa é a guerra de mundos que constitui o pano de fundo agonístico da cosmopráxis indígena (...) Quem quer que responda a um "tu" dito por um não humano aceita a condição de "segunda pessoa" do outro, e quando por sua vez assumir a posição de "eu", já o fará como não humano". A forma canônica de tais encontros consiste, portanto, em descobrir repentinamente que o outro é "humano", isto é, que é o outro o humano, o que automaticamente desumaniza e aliena o interlocutor (DE CASTRO, 2011).

Seria preciso entender a lógica comunicativa vigente segundo o problema político do perspectivismo: como não ser capturado por um ponto de vista mais poderoso? (VALENTIM, 2019). A binarização discursiva em que estamos imersos produz a objetificação do outro, daqueles e daquelas que diferem, com o intuito de reduzir os mundos outros a meros objetos de um só mundo. Acontecimentos como as revoltas de Junho, no entanto, deixam em evidência esse procedimento político-semiótico internalizado. Um episódio das manifestações é exemplar sobre tal procedimento. Refiro-me ao caso da prisão de Bruno Teles ${ }^{3}$. Em 22 de julho de 2013, na rua do Palácio Guanabara, na capital fluminense, em mais uma passeata contra os Grandes Eventos, uma multidão afrontou

3 Sobre o caso, ver reportagem disponível em: http://g1.globo.com/rio-de-janeiro/noticia/2013/07/video-mostrabruno-sem-bomba-na-hora-em-que-coquetel-e-lancado.html. Acesso em: 1 out. 2017. Também, o documentário, feito pelo Coletivo Carranca, disponível em: https://www.youtube.com/watch?v=ijfBvGGVuXM. Acesso em: 1 out. 2017. Vale dizer que é difícil encontrar essa memória no acervo digital da Globo. Há menção ao episódio em várias reportagens do portal de notícias G1, mas a grande maioria dos vídeos está desativada. Não deixa de ser algo relevante. Outra referência sobre o episódio, ver Lorenzotti (2014). 
a Polícia Militar do Rio de Janeiro (uma das mais letais do planeta). A razão do tumulto decorreu do lançamento de um coquetel molotov na direção do ajuntamento policial, que então formava um cordão de isolamento para impedir o acesso à sede do governo. A essa altura das revoltas, apesar da PM operar altamente aparelhada com os mais sofisticados gadgets de controle de distúrbios, a resistência já possuía um certo saber-fazer de como se movimentar nas circunstâncias de combate.

Após alguns momentos intensos de enfrentamento, a PM prendeu Bruno Teles, sob a acusação de que teria sido ele quem alvejara a polícia com a bomba caseira. A repercussão do caso foi desproporcional. Vale lembrar que essa foi a mesma manifestação em que jornalistas da Mídia Ninja foram presos, um deles fazendo, ao vivo, streaming da própria prisão. A imprensa, sobretudo a TV Globo, mobilizou todo o seu dispositivo jornalístico, dedicando horas (sabemos o valor que custa cada segundo veiculado na emissora) ao assunto em seus telejornais, para sentenciar Bruno Teles culpado, antes de qualquer julgamento, e, por ensejo, criminalizar toda a movimentação.

Essa criminalização é fruto de um procedimento semiótico. No caso das revoltas e nesse episódio particular, a lógica semiótica estruturada estabeleceu quem era o eu que deve falar e o tu sobre o qual se fala e que deve calar, isto é, quem ocupava a posição de sujeito de enunciação e de objeto do enunciado das perspectivas expressas. Nos termos da semiótica perspectivista (ou de uma semiótica selvagem), tratava-se de demarcar quem era o predador e quem era a presa, quem era o agente e o paciente naquele perigoso encontro. Comandantes da polícia, promotores públicos, juristas especialistas em balística, todo um jogo discursivo foi instituído para que, coordenadamente com um conjunto de práticas jurídicas, o vândalo se transmutasse em um corpo sem humanidade (sem perspectiva), reles coisa, objeto passível de intervenção política, pela sua própria condição de nãohumano, de vândalo.

Essa manifestação foi, no entanto, captada por uma série de animais-cinéticos (Bentes, 2014), de coletivos autônomos de mídia. Da delegacia, preso preventivamente, Bruno Teles concedeu sorrateiramente entrevista para a Mídia Ninja na qual requisitava ajuda de quem tivesse filmado o protesto e pudesse compartilhar imagens para tentar comprovar sua inocência. No dia seguinte, um vídeo composto por uma multidão de imagens díspares não só mostrava não ter sido ele o agente, como também exibia sua covarde prisão. Além disso, as imagens mostravam que tinha sido um policial infiltrado, um P2, quem jogou o explosivo que engatilhou o tumulto.

O vídeo viralizou nas redes sociais. No dia 25 de julho, a Globo teve de rever sua posição, recorrendo, inclusive, às imagens dos coletivos autônomos de mídia pela primeira vez na história, desfazendo as alegações dos procuradores de Justiça e da PM, que foram ao ar no "Jornal Nacional" do dia anterior. O aparato Policial-Midiático não teve outra opção a não ser assumir a perspectiva dos corpos em revolta. O mundo da Mídia-Estado não se efetivou. A revolta não se transmutou em objeto do enunciado, erigiu, ao contrário, 
como sujeito de enunciação, como agenciamento coletivo de enunciação. As revoltas fizeram valer sua perspectiva. O mesmo pode ser dito sobre o caso de Amarildo.

Dois anos depois, em documentário sobre o ocorrido, Bruno Teles avaliou assim a transformação perspectivista que experimentou: "Na noite passada eu era um criminoso incendiário, no outro dia eu era um menino, filhinho de família, um estudante, coitado do cara". Bruno Teles esteve prestes a ser devorado como objeto pela grade de dispositivos da Mídia-Estado que cotidianamente produz processos de significação que objetificam o outro. Bruno Teles era vândalo/manifestante ao mesmo tempo. A variar o ponto de vista, o mundo em que estava era completamente outro. Em um mundo, ele era dotado de humanidade, menino, filhinho de família, estudante, no outro, era o objeto, sem estatuto de humano, criminoso, incendiário. As revoltas de Junho ampliaram radicalmente, ou melhor, deixaram evidente a amplitude e as multiplicidades de enunciação que se agitam cotidianamente à espera do bote a despeito do perigo de objetificação que o encontro com o predador na mata, o Estado-Mídia, pode atualizar.

O pensamento selvagem afirma que todos os povos da Terra, humanos, nãohumanos, extra-humanos, possuem, de direito e de fato, uma potência de autodeterminação ontológica, de dizer eu ou nós. Desse princípio metodológico, desse anarquismo ontológico, deriva um perspectivismo semiótico (uma epistemologia) segundo o qual o estatuto do sujeito de enunciação é incerto e se estende virtualmente a todos os seres existentes no cosmos. A inconstância, a indeterminação e a permutação subjetiva são pressupostos fundamentais. A semiótica perspectivista tenta extrair dessa lógica uma política da significação, um procedimento de rastreio de quem está ocupando, em acontecimentos sociocomunicacionais, a função de sujeito de enunciação e a função de objeto do enunciado, de predador e de presa.

As revoltas de Junho demonstraram que em determinadas condições torna-se impossível transformar a alteridade, o outro, em presa, em objeto, em coisa desprovida de humanidade. O agenciamento da revolta não respondeu a interpelação do Estado-Mídia. Eles afirmaram ininterruptamente sua condição de agenciamento coletivo de enunciação. Sempre que eram acusados de vândalos ou de violentos retrucavam invariavelmente: violento é o Estado. O processo de significação aparece como o que é, de fato: uma disputa político-semiótica para ver quem alçará ao estatuto de sujeito de enunciação e quem será objetificado. O objeto e o sujeito são o efeito de um processo político-semiótico que os precede e os constitui. "A linguagem é caso de política antes de ser caso de linguística" (DELEUZE; GUATTARI, 2012, p. 82). Sujeito e objeto são formalizados por meio de uma emaranhada teia de forças, práticas e discursos, tendo em vista demarcar quem expressará o sentido último a respeito do que aconteceu. No fundo, não há objeto algum, ou, melhor: "O mais subjetivo será o mais objetivo" (DELEUZE; GUATTARI, 2012, p. 18). A verdadeira questão é saber o quem das coisas. 


\section{Conclusão}

Fazer uma leitura das revoltas de Junho no terreno do perspectivismo multinaturalista tem uma razão de ser específica. Por ser a revolta uma expressão evidente da natureza da multiplicidade em transformação de todos os fenômenos sociais, somos lançados, assim, a rever nossas bases epistêmicas fundamentadas em um mundo cindido entre natureza e cultura. Privilegiar a revolta nessa análise se deve ao fato dela configurar ao mesmo tempo uma ruptura aberrante com o estado de coisas de um bloco de significação geohistórico específico e um fenômeno em que se vê com maior facilidade o aspecto não amorfo e inerte de todo e qualquer fenômeno social ${ }^{4}$. Se mudamos o referencial de observação dos fenômenos e privilegiamos a perspectiva, o puro fluir em movimento sem identidade fixa ou permanente, talvez concluamos que sujeito e objeto, em qualquer manifestação acontecimental, são efeitos de uma política de significação instaurada e não condição de possibilidade dos discursos.

Ler os acontecimentos sociocomunicacionais hodiernos segundo os personagens conceituais predador e presa nos permite nuançar exatamente a política de significação que hoje governa a esfera pública brasileira, com uma diferença: na antropológica ameríndia a epistemologia da predação humaniza o alheio para devorá-lo, enquanto na antropológica moderna a epistemologia desumaniza o alheio para objetificá-lo. O caráter inconstante e vário dessas posições enunciativas torna mais evidente o que de fato constitui a política de significação Ocidental: objetificar a diferença. Se a linguística de Saussure começou afirmando, com razão, que o ponto de vista cria o objeto, a semiótica perspectivista propõe que o ponto de vista cria o sujeito. Ou melhor: eles são co-emergentes, são os dois e mais, ao mesmo tempo.

Entretanto, é difícil estabelecer uma leitura semiótica de uma ecosfera na qual os corpos são todos possíveis focos de enunciação, em que cada coisa do mundo é virtualmente um agente, uma ameaça constante de um desejo. Como formular um diagnóstico com pontos de apoio instáveis, sem dualidades prescritivas? Isso porque a perspectiva que prevalecer sobre as demais causará impactos, talvez, irreversíveis para os agenciamentos que, por acaso, perderem, ainda que momentaneamente, a disputa pelos sentidos dos acontecimentos. Esse é um problema de paradigma ético-estético. É possível manter a multiplicidade de mundos, sem recair em consensos, colonialismos, racismos, autoritarismos, preservando, ao invés, a possibilidade do dissenso das perspectivas, a possibilidade de variação dos mundos? Como calibrar um procedimento semiótico que nos proveja elementos conceituais adequados para esse tipo de leitura?

4 Poderíamos abrir uma seção para explicitar o quanto o perspectivismo multinaturalista é devedor da filosofia de Deleuze e Guattari. Não é por acaso que o subtítulo de Metafísicas Canibais (2013) é: elementos para uma antropologia pós-estrutural. No início da introdução, Viveiros de Castro anuncia que o projeto primeiro do livro era o de ser o que Anti-Édipo foi para a psicanálise. O título seria $O$ Anti-Narciso, que funcionaria igualmente para destituir o paradigma que orienta, grosso modo, a semiologia e a teoria da comunicação dominantes. 
Formular assim o problema é um exercício de leitura dos signos que tem por objetivo fugir do multiculturalismo semiótico. Pensar os devires possíveis de um tal acontecimento exige e permite uma fuga das aporias do reducionismo ideológico das políticas e epistemologias exclusivamente identitárias e polarizadas (foi de direita, não, foi de esquerda, quando pode ter sido ambos ao mesmo tempo, e muito mais). A semiótica perspectivista afirma ser indispensável a inclusão do ponto de vista do outro previamente a qualquer processo de objetificação com o fim de ampliar os focos enunciativos e não reduzir ou bloquear esse vir-a-ser. Todos os corpos do mundo são um grau de potência, objetificá-los, transformá-los em objeto do enunciado, pura e simplesmente, sem considerar essa condição ontológica é a reprodução do colonialismo em outros termos. Torna-se urgente, assim me parece, conceber um sistema de avaliação semiótico que não funcione como um dispositivo de destruição de mundos - (isso fica evidente no enunciado menos famoso, mas um dos mais fortes afirmados no correr das revoltas, a saber: a Imprensa é o braço armado da Polícia...). Uma semiótica que seja um exercício de descolonização permanente da linguagem e da comunicação. Não é outra a proposta de uma semiótica perspectivista.

André Fogliano é doutor pelo Programa de Estudos Pósgraduados em Comunicação e Semiótica na PUC-SP com pós-doutorando no Centro de Estudos em Sociedade e Cultura da Concordia University, em Montreal, sob a orientação de Erin Manning. É pesquisador associado do Senselab (Canadá) e do Centro Interdisciplinar de Pesquisa em Comunicação e Cibercultura (CENCIB) e do Grupo de Pesquisa em Mídias, Um dia sete dias, ambos sediados na PUC-SP. Tradutor do livro The Minor Gesture, de Erin Manning (no prelo).

andre.fogli@gmail.com

\section{Referências}

ALZAMORA, G; RODRIGUES, T. Fora Rede Globo: a representação televisiva das Jornadas de Junho em conexões intermídia. In: Revista Eco-Pós, v. 17, n. 1, 2014. Rio de Janeiro: UFRJ, 2014. Disponível em: https://revistas.ufrj.br/index.php/eco_pos/article/view/1288/pdf_17. Acesso em: 16 nov. 2019.

BARTHES, R. Elementos de semiologia. São Paulo: Cultrix, 2006.

BENTES, I. Mídia-multidão. Rio de Janeiro: Mauad, 2014.

COCCO, G; CAVA, B. O enigma do disforme: neoliberalismo e poder no Brasil global. Rio de Janeiro: Mauad, 2018. 
DE CASTRO, E. V. Os pronomes cosmológicos e o perspectivismo ameríndio,1996. Disponível em: http://www.scielo.br/scielo.phpscript=sci_arttext\&pid=S010493131996000200005\&lng=en\&nrm= iso. Acesso em: 13 jul. 2018.

A inconstância da alma selvagem. São Paulo: Cosac Naify, 2002.

. O medo dos outros. In: Revista de Antropologia, v. 54, n. 2. São Paulo: USP, 2011. Disponível em: https://www.revistas.usp.br/ra/article/view/39650/43146. Acesso em: 2 out. 2017.

Metafísicas canibais: elementos para uma antropologia pós-estrutural. São Paulo: N-1 Edições e Cosac Naify, 2015.

DA COSTA, R. A noção de hábito em Espinosa e Peirce. Cognitio, v. 17, n. 2. São Paulo: PUC-SP, 2016. Disponível em: https://revistas.pucsp.br/index.php/cognitiofilosofia/article/view/31232. Acesso em: 21 fev. 2019.

DELEUZE, G; GUATTARI, F. O Anti-Édipo. Rio de Janeiro: Imago, 1976.

. Mil platôs: capitalismo e esquizofrenia 2, Vol. 2. São Paulo: Editora 34, 2012.

DEMURU, P. O corpo da nação. Um olhar sociossemiótico sobre o Brasil de junho de 2013 aos dias de hoje. In: OLIVEIRA, A.C.M.A (org.). Semiótica do Social. São Paulo: Estação das Letras e Cores, 2018.

Ficção seriada televisiva, jornalismo político e construção do real: hipóteses a partir de Greimas. Significação: Revista De Cultura Audiovisual. São Paulo, v. 44, n. 48, 2017.

JOURDAN, C. 2013: Memórias e resistências. São Paulo: Editora Circuito, 2018.

LORENZOTTI, E. Jornalismo século XXI: o modelo \#mídiaNinja. E-Galáxia, 2014. Disponível em: http://www5.usp.br/wp-content/uploads/Ninja_Imprensa.pdf. Acesso em: 10 abr. 2017.

PRADO, J. L. A; PRATES, V. O significante 'povo brasileiro' na crise política do impeachment de Dilma Rousseff. In: PRIOR, H; GUAZINA, L; ARAÚJO, B. (Org.). (Des)construindo uma queda: a mídia e o impeachment de Dilma Rousseff.Florianópolis: Insular, 2019.

. O afastamento de Dilma Rousseff: afetos e discursos em disputa na política. Revista Famecos. Porto Alegre, v.26, n.2, 2019.

MBEMBE, A. Crítica da razão negra. São Paulo: N -1 Edições, 2017.

SCHAVELZON, S. "O caminho esquecido contra o que ainda nos consome", In: Urucum, 22 Set.2017. Disponível em: https://urucum.milharal.org/2017/09/22/o-caminho-esquecido-contra-o-que-aindanos-consome/. Acesso em: 22 set. 2017.

VALENTIM, M. Extramundanidade e sobrenatureza: ensaio de ontologia infudamental. Florianópolis: Cultura e Barbárie, 2019.

Texto recebido em 16/12/2018

e aprovado em 27/10/2019. 